\title{
Cryopreservation of Erythrocytes, Thrombocytes, and Lymphocytes
}

\author{
Andreas Sputtek ${ }^{\mathrm{a}}$ Peter Kühnl ${ }^{\mathrm{a}} \quad$ Arthur W. Rowe \\ ${ }^{a}$ Institut für Transfusionsmedizin, Universitätsklinikum Hamburg-Eppendorf, Hamburg, Germany \\ ${ }^{b}$ New York University School of Medicine, New York, NY, USA
}

\section{Key Words}

Cryopreservation - Freezing - Erythrocytes .

Thrombocytes · Lymphocytes · Glycerol · Dimethyl

sulphoxide $\cdot$ Hydroxyethyl starch

\section{Summary}

The cryopreservation of blood cells can be regarded as a classical field of development and application of low temperature biology. Cryopreservation methods have been developed for erythrocytes, which are commonly frozen with glycerol as the cryoprotective additive although hydroxyethyl starch (HES) shows considerable promise. Cryopreserved erythrocytes for transfusion are of advantage in the case of patients with rare blood groups, adverse antibody problems, autologous use and civil as well as military disasters. Additionally they can be used for blood typing, antibody screening and compatibility testing. Cryopreservation methods for thrombocytes, lymphocytes and hematopoietic stem cells usually involve dimethyl sulfoxide (DMSO) as the cryoprotective additive. Low temperature preservation of thrombocytes offers the possibility of making HPA- and/or HLA-typed platelet concentrates available in blood banks at any time. The use of cryopreserved lymphocytes is well established and a routine procedure for clinical laboratory testing. Recently there is a growing clinical interest in cryopreserved lymphocytes in addition to hematopoietic progenitor cells for the supplemental treatment of patients after blood stem cell transplantation. Despite occasional reports, it is our opinion that no clinically suitable method for the preservation of human granulocytes has been developed so far.

\author{
Schlüsselwörter \\ Kryokonservierung · Einfrieren · Erythrozyten . \\ Thrombozyten · Lymphozyten · Glycerin . \\ Dimethylsulfoxid · Hydroxyethylstärke
}

\section{Zusammenfassung}

Die Kryokonservierung von Blutzellen stellt eine klassische Entwicklung und Anwendung der Tieftemperaturbiologie dar. Die für Erythrozyten entwickelten Methoden bedienen sich im Allgemeinen des Kryoprotektivs Glycerin, obwohl auch die Verwendung von Hydroxyethylstärke (HES) vielversprechend ist. Kryokonservierte Erythrozyten zur Transfusion sind von Vorteil bei Patienten mit seltenen Blutgruppenmerkmalen, bei Problemen mit bestimmten Antikörpern, zur Bevorratung mit Eigenblut und im Falle ziviler oder militärischer Katastrophen. Darüber hinaus können sie aber auch bei der Blutgruppenbestimmung, der Antikörpersuche und der Verträglichkeitstestung eingesetzt werden. Kryokonservierungsverfahren für Thrombozyten, Lymphozyten und hämatopoetische Blutstammzellen verwenden im allgemeinen Dimethylsulfoxid (DMSO) als Kryoprotektiv. Die Tieftemperaturkonservierung von Thrombozyten erlaubt die Bevorratung von HPA- und/oder HLA-typisierten Plättchenkonzentraten. Der Gebrauch von tiefgefrorenen Lymphozyten ist etabliert für die Durchführung bestimmter Tests in klinischen Laboratorien. In den letzten Jahren hat das Interesse an kryokonservierten Lymphozyten zur ergänzenden Therapie nach der Blutstammzell-Transplantationen deutlich zugenommen. Trotz bisweilen in der Literatur auftauchender Berichte wurde aber nach unserer Einschätzung noch kein zufriedenstellendes Verfahren zur Kryokonservierung von humanen Granulozyten gefunden.

\begin{tabular}{ll}
\hline KARGER & @ 2007 S. Karger GmbH, Freiburg \\
Fax +49 76145207 14 & Accessible online at: \\
$\begin{array}{l}\text { E-mail Information@Karger.de } \\
\text { www.karger.com }\end{array}$ & www.karger.com/tmh
\end{tabular}

Dr. Andreas Sputtek 


\section{Introduction}

Frozen erythrocytes, thrombocytes, lymphocytes and hematopoietic progenitor cells (from peripheral blood as well as from bone marrow) are being used for various diagnostic and therapeutic purposes [reviews in e.g. 1-3]. A variety of cell-specific cryopreservation protocols have evolved so far. The methods differ with regard to i) cell concentrations, ii) protective solutions used (cryoprotectants and their concentrations), iii) temperature-time histories (TTH) during cooling and re-warming, and iv) storage temperature. Additionally, some of the cryoprotectants are not well tolerated clinically in the concentrations required for cryopreservation (e.g. dimethyl sulfoxide (DMSO) for platelets) or lead to an osmot ically induced lysis of the cryoprotectant-loaded cells when transfused into an isotonic individual organism (e.g. glycerol for erythrocytes). In these cases, a washing procedure is required after thawing to remove the cryoprotective additive prior to the application/transfusion.

\section{Erythrocytes}

\section{Clinically Applied Methods Using Glycerol}

In principle, three different methods have been established for routine clinical use of frozen red cells (RBC) [4]; these are:

i) The Huggins [5] technique utilizes $40 \%$ [wt/v] glycerol as the cryoprotective additive. Prior to transfusion the glycerol is removed by reversible agglomeration of the RBC using nonionic sugar solutions. Initially used by many hospitals, this procedure is rarely used now because of unavailability of required equipment and disposable supplies.

ii) The 'high glycerol slow cooling technique' according to Meryman and Hornblower [6] utilizes $40 \%$ [wt/v] glycerol and washing with concentrated salt solutions prior to transfusion. This is the dominant method in use in the USA [for details see 7,8].

iii) The 'low glycerol-rapid cooling technique' according to Rowe [9, 10] and Krijnen et al. [11] utilizes $~ 17-19 \%$ $[\mathrm{wt} / \mathrm{v}]$ glycerol and rapid cooling in liquid nitrogen $\left(\mathrm{LN}_{2}\right)$. Storage of frozen material must be in $\mathrm{LN}_{2}\left(-196^{\circ} \mathrm{C}\right)$ or its vapor $\left(\leq-165^{\circ} \mathrm{C}\right)$. This is the dominant method for cryopreservation of RBC in Europe [detailed description in 8].

\section{Methods Using Macromolecular Additives}

The utilization of macromolecular cryoprotectants is an alternative approach to using glycerol for cryopreservation of erythrocytes. Watersoluble, cryoprotective macromolecules such as albumin, dextrans, modified gelatin, polyvinylpyrrolidone (PVP), polyethylene oxide (PEO), polyethylene glycol (PEG) and hydroxyethyl starches (HES) exhibit the principal advantage of not entering into the cells. This property significantly

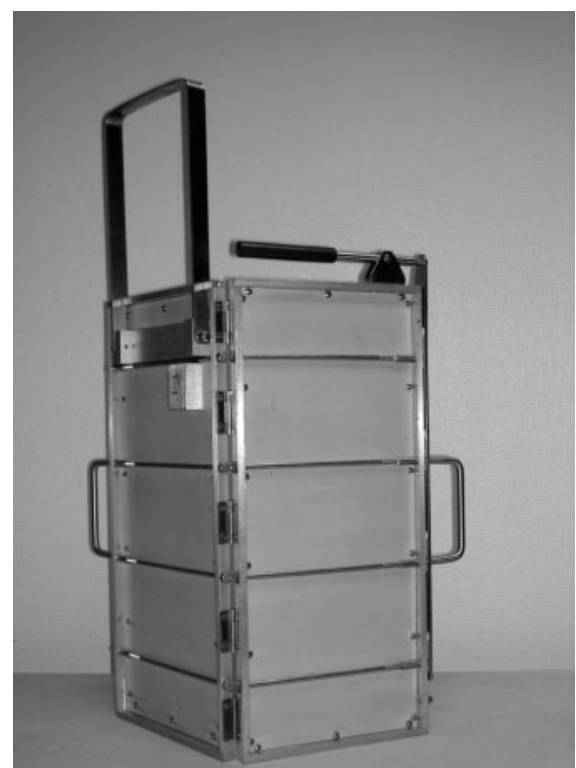

facilitates their removal after thawing. In the case of emergencies, this step could be omitted if the additive, e.g. albumin, dextrans, modified gelatin or HES, is biodegradable and tolerated by the human organism.

\section{Cryopreservation with Hydroxyethyl Starch}

Early studies on macromolecular cryoprotectants go back to Rinfret and coworkers [12] who utilized PVP successfully for freezing erythrocytes. In 1967 Knorpp and co-workers [13] described the successful cryopreservation of human RBC using HES and liquid nitrogen $\left(\mathrm{LN}_{2}\right)$. Comparing the efficacy of HES to that of PVP, they preferred the colloid HES to PVP as the latter is retained to a considerable extent in the recipient (as are PEO and PEG). Moreover, in the case of hypovolemia, albumin, dextrans, modified gelatins and HES are often transfused to serve as blood volume substitutes.

After several in vitro investigations and optimizations of the original HES procedure $[14,15]$ and after in vivo experiments in dogs, Sputtek and coworkers [16] conducted a successful in vivo study including seven healthy volunteers. They subsequently performed a systematic clinical trial in patients [17]. A detailed description of the method for the clinical application can be found in [8], and a review of the development of the procedure in [18]. Nota bene: The patented freezing container (fig. 1 [19]) which must be used has a wall thickness of $2 \mathrm{~mm}$. The exterior is pasted with a microporous textile tape to improve the heat transfer during the cooling process in boiling $\mathrm{LN}_{2}$. Cooling rates of approximately $70{ }^{\circ} \mathrm{C} / \mathrm{min}$ that result from the use of uncoated containers are too low compared with those required (i.e. $200-250{ }^{\circ} \mathrm{C} / \mathrm{min}$ in the temperature range between $0{ }^{\circ} \mathrm{C}$ and $-30{ }^{\circ} \mathrm{C}$ ). Additionally, the closed container produces a well defined flat geometry of the bags and a homogenous sample thickness (approximately 5-6 mm). $\mathrm{LN}_{2}$ is not allowed to come into contact with the samples during 
Fig. 2. Shaking water bath, modified with a pouch for rapid thawing as described in [8].

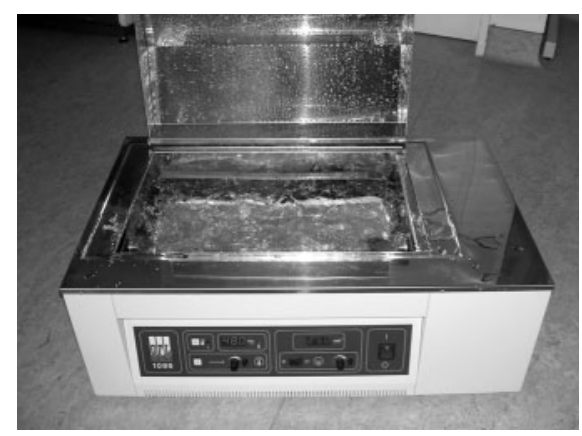

the initial cooling process. Please note that you will not be able to reproduce our results when not using the patented freezing container. Rapid thawing is needed as well: This can be achieved by using a shaking water bath with a pouch (fig. 2 [8]). The reason is that the composition of the cell suspension (e.g. hematocrit, HES concentration, electrolyte content), sample thickness, geometry and cooling rate are interdependent: A change in one of these parameters will lead to a less favorable result.

Based on the work published by Robson [20], Thomas and coworkers [21, 22] have developed a modified procedure for the freezing of RBC using HES. The major differences compared to our procedure are: i) no pre-freeze washing, ii) different HES modification, iii) lower HES concentration, iv) higher electrolyte concentration, v) higher hematocrit, vi) larger freezing bag, vii) smaller sample thickness, viii) smaller volume, ix) higher viscosity, $\mathrm{x}$ ) different freezing container, and xi) uncontrolled thawing. Unfortunately, because of high viscosity, they must dilute or wash out the HES prior to transfusion because of poor flow rate of the concentrated HES-erythrocyte mixture.

As we have pointed out, it is essential to remove white cells and platelets prior to freezing. Thomas et al. [22] have speculated that the contents of the white cells and platelets are highly thromboplastic. As these cells are destroyed on freezing, thereby liberating their contents into the HES/RBC mixture, failure to filter could cause a disseminated intravascular coagulopathy when the RBC are subsequently thawed and transfused without post-thaw washing.

Cryobiological researchers and clinical colleagues interested in our HES method for freezing erythrocytes have posed questions regarding the nature of HES and where it can be obtained. The following 2 paragraphs address some of these issues.

\section{Structure of HES}

HES is a modified natural polymer of branched amylopectin (one of the two components of starch, the other component is the linear amylose). Its physical and chemical characteristics are mainly defined by i) the degree of hydroxyethylation (DS), i.e. replacement of hydroxyl groups of the anhydroglucose units by hydroxyethyl groups) and ii) the molecular weight distribution. Whereas native starch is hardly watersoluble, hydroxyethylation increases water solubility. DS is determined by measuring the number of substituted anhydroglucose units and dividing this number by the total number of anhydroglucose units in the molecule. The molar substitution (MS) is calculated by measuring the total number of hydroxyethyl groups present and dividing this by the total number of anhydroglucose units. DS and MS are not the same, but they are often incorrectly used interchangeably in the literature. As hydroxyethylation can occur at carbon positions 2,3 or 6 of the anhydroglucose unit, depending of the manufacturing process, the substitution pattern can vary greatly. HES molecules show a great polydispersity (in contrast to other cryoprotectants such as glycerol and DMSO, which have molecular weights of $92.09 \mathrm{~g} / \mathrm{mol}$ and $78.13 \mathrm{~g} / \mathrm{mol}$, respectively. The molecule sizes of HES usually follow a sort of bell-shaped distribution, ranging from some thousand $\mathrm{g} / \mathrm{mol}$ to over a million $\mathrm{g} / \mathrm{mol}$. Consequently 'the molecular weight' can by regarded as an 'average' molecular weight only. There are two ways for the calculation: i) arithmetic mean, i.e. total weight of all molecules dived by the number of molecules $\left(\mathrm{M}_{\mathrm{n}}\right)$ and weight averaged mean $\left(\mathrm{M}_{\mathrm{w}}\right)$. For example, an HES specified as '450/0.7' should be an HES with an $\mathrm{M}_{\mathrm{w}}$ of $450,000 \mathrm{~g} / \mathrm{mol}$ and an MS of 0.7 (i.e. 70 hydroxyethyl groups per 100 anhydroglucose units of the polymer). A comprehensive overview on the structure of HES can be found in Banks et al. [23]. Of major importance is that HES, a plasma volume expander, is metabolized by the body and excreted unlike some other macromolecules (e.g. PEO, PVP).

\section{HES Solutions}

For historical and marketing reasons, predominantly slowly degradable, high $\mathrm{M}_{\mathrm{W}}$ HES (450/0.7) is available in the USA. In Europe, a large variety of HES solutions is available, dominated by medium $\mathrm{M}_{\mathrm{W}}$, easily degradable HES (200/0.5) [24]. The optimized HES solution used in our clinical trials with patients (KryoHAES ${ }^{\circledR}$, manufactured by Fresenius, Bad Homburg, Germany, according to our specifications) had an HES concentration of $23 \%(\mathrm{wt} / \mathrm{wt})$ which equals $25 \%(\mathrm{wt} / \mathrm{v})$. This is higher than the $3 \%(\mathrm{wt} / \mathrm{v}), 6 \%(\mathrm{wt} / \mathrm{v})$ or $10 \%(\mathrm{wt} / \mathrm{v})$ solutions available for clinical use. The sodium chloride concentration of $60 \mathrm{mmol} / \mathrm{l}$ was lower than the 'standard' $155 \mathrm{mmol} / \mathrm{l}$. The average $\mathrm{M}_{\mathrm{W}}$ and the DS were $200,000 \mathrm{~g} / \mathrm{mol}$ and 0.5 , respectively. Although it is commercially not available at present, it can be prepared from dry HES powder or commercially available HES solutions after dialysis and freeze drying [25, 26]. The dry substance can be dissolved in distilled water and the appropriate amount of sodium chloride has to be added. Suppliers of dry HES powder (with different amounts of low molecular weight impurities (= LMWI, see below) are e.g. Ajinomoto (Japan), Fresenius Kabi (Germany), and Serum Werk Bernburg (Germany). Suppliers of HES solutions for infusion in Germany are e.g. Baxter, B. Braun, Fresenius Kabi, Serag-Wiesner, and Serum Werk Bernburg. In principle any 
dialysis tubes from any supplier can be used, as long as the cut-off is about $10,000-14,000 \mathrm{~g} / \mathrm{mol}$. HES concentrations should not be higher than $10 \%$ (wt/wt), as otherwise the tubes may crack during the procedure. Nota bene: If the decision is made to use a ready-made solution provided by one of the above mentioned companies, it has to be determined by trial and error if it works. If the solution contains too many LMWI (i.e. electrolytes, oligosaccharides) it may not work. A product named 'Hydroxyethyl starch', product code $\mathrm{H}$ 6382, from Sigma-Aldrich should never be used for another reason. Only an average of 10 per 100 anhydroglucose units are substituted with a hydroxyethyl group (DS $=0.1$ ). As a consequence it is poorly soluble in water. A product which is called 'Hetastarch' [for nomenclature of HES in the USA see 24], product code $\mathrm{H}$ 2648 , from the same company can be used. It comes as a $6 \%$ solution in $0.9 \%$ sodium chloride. However, this is very expensive (approximately EUR 15.- per gram HES) compared to the 3,6 or $10 \%$ solutions used in the intensive care units in hospitals. HES has been used for many decades as a volume replacement after blood loss. The cost for HES in plasma substitutes is approximatley EUR 0.33 per gram HES). The modifications familiar for this purpose in Europe are 450/0.7, $200 / 0.5,130 / 0.4$ and $70 / 0.5$. The concentrations vary from 3 to $10 \%(\mathrm{wt} / \mathrm{v})$ and the electrolyte content is adjusted to isotonicity (mostly by adding sodium chloride). The solutions available for volume replacement may contain various amounts of LMWI, these may differ from one HES modification to the other, and sometimes even from one lot to the next from the same manufacturer. If this is not taken into account, it will be difficult to reproduce the work.

\section{Determination of RBC Recovery/Viability}

The determination of cell recovery/viability after thawing in the presence of HES poses a problem. HES coats the surface of the erythrocytes and may provide a scaffolding for damaged membranes so that some cells appear intact, though they will rupture if diluted with isotonic saline. Viability after thawing, in terms of 'saline stability', can be determined as follows [14]: $250 \mu \mathrm{l}$ of the RBC suspension is diluted 40-fold in a buffered isotonic saline solution. After $30 \mathrm{~min}$ the suspension is separated into a supernatant (destroyed RBC) and sediment (intact RBC) by centrifugation. Saline stability is then calculated using:

Saline stability $[\%]=\left(1-\mathrm{Hb}_{\mathrm{S}} / \mathrm{Hb}_{\mathrm{T}}\right) \times 100$,

where $\mathrm{Hb}_{\mathrm{T}}$ corresponds to the total hemoglobin and $\mathrm{Hb}_{\mathrm{s}}$ to the hemoglobin in the supernatant. The determination of the 2 hemoglobin concentrations can be performed spectrophotometrically at $546 \mathrm{~nm}$ using Drabkin's solution. A correction for the hematocrit is not required, as the volume fraction of erythrocytes after 40 -fold dilution is less than $2 \%$. Plasma stabilities (i.e. when plasma is used as diluent in the test instead of isotonic saline) may be slightly higher than saline stabilities because plasma factors allow a few very slightly damaged cells to recover. In the presence of HES (and other macromolecular cryoprotectants!) the post-thaw recovery of intact cells, determined by simply spinning down the suspension without any dilution and measuring the percentage of 'free' hemoglobin, should not be used as a quality control procedure because the result is misleading, irrespective of the hematocrit being taken into consideration or not.

\section{Thrombocytes}

Since the first reported attempt in 1956 to stop thrombocytopenic bleeding by the infusion of previously frozen platelets by Klein [27], a broad variety of in vitro and in vivo studies on cryopreserved platelets have been published. Djerassi et al. [28] in 1966 were the first to report on the use of 5\% DMSO and cooling at $1 \mathrm{C} / \mathrm{min}$ for successful cryopreservation and transfusion of human platelets. As no removal of DMSO after thawing was performed, the recipients suffered from problems arising from infusion of this substance. The introduction of a post-thaw washing procedure by Lundberg et al. [29] helped to overcome the symptoms of nausea, vomiting, local vasospasm and a garlic-like odor and taste. The most widely used method for the cryopreservation of platelets is a ' $10 \%$ DMSO-slow cooling' method tested clinically by Schiffer $[3,8$, 30,31 ] while another approach is a 'low glycerol/glucose-intermediate cooling' method described by Dayian and Rowe in $1976[1,32]$.

HES-cryopreserved platelets (frozen in the presence of $4 \%$ (wt/v) HES at $1{ }^{\circ} \mathrm{C} / \mathrm{min}$ ), turned out to be hemostatically effective when using a $4 \%$ HES method [33]. Optimum results can only be achieved when increasing the cooling rate from $1{ }^{\circ} \mathrm{C} / \mathrm{min}$ as described by Choudhury [33] to $15 \pm 5^{\circ} \mathrm{C} / \mathrm{min}$ and reducing the sodium chloride concentration in the cryoprotective solution from isotonic to $120 \mathrm{mmol} / \mathrm{l}[8,34]$. When comparing the optimized HES method to Schiffer's technique [30, 31], both protocols turned out to be highly effective regarding the post-thaw numerical platelet recovery (approximately $90 \%$ ). However, functional in vitro parameters showed that the DMSO-protected frozen platelets were inferior to fresh controls but superior compared to the HES-protected ones [35].

\section{Lymphocytes}

The use of cryopreserved mononuclear cells (which includes lymphocytes) is well established and a routine procedure for clinical laboratory testing. Cohen and Rowe [36] were the first to report on detection of leukoagglutinins with frozen lymphocytes for transfusion compatibility, a forerunner of tissue typing plates in common use for detection of HLA (human leukocyte antigen) antibodies. Today frozen lymphocytes are 
used for various diagnostic purposes, e.g. HLA typing, detection of HLA antibodies in patients on waiting lists for organ/ bone marrow transplantations and mixed lymphocyte reactions/cultures. They are also of interest with respect to lookback procedures in transfusion medicine or diagnosis in patients. The methods for freezing mononuclear cells reported in the literature vary from one author to another [1-3]. Recently, there is a growing clinical interest in cryopreserved lymphocytes for the supplemental treatment of patients after blood stem cell transplantation making use of the 'graft-versusleukemia' effect in the case of relapse. Usually, those peripheral donor lymphocytes are frozen according to methods which are more or less modifications of a technique which was first described for bone marrow by Ashwood-Smith [37] in 1961 using 10\% DMSO. During cooling, the heat is removed either by computer-controlled and $\mathrm{LN}_{2}$-operated machines or in mechanical $\left(-80{ }^{\circ} \mathrm{C}\right)$ refrigerators. Cryopreserved autologous and homologous blood stem cells - which are mononuclear cells as well - have become a 'standard' blood component for the treatment of several malignant diseases. Stiff and co-workers [38] have reported that the addition of $6 \%$ HES reduced the 'original' concentration of DMSO $(10 \%)$ by one half. Optimum results for peripheral blood stem cells can be obtained when using cooling rates between 1 and $5{ }^{\circ} \mathrm{C} / \mathrm{min}$ and at least 5\% DMSO are present [39]. A detailed review of the various procedures for hematopoietic stem cells (in German) can be found elsewhere [40].

If mononuclear cells are to be frozen for laboratory purposes, cell concentrations may range from $0.5 \times 10^{6}$ to $50 \times 10^{6} / \mathrm{ml}$, the most frequently used medium is RPMI 1640 supplemented with human or fetal calf serum or plasma, and the cryoprotectant of choice is $5-10 \%$ DMSO. Cooling is performed in 1 or $2 \mathrm{ml}$ vials at $1-2{ }^{\circ} \mathrm{C} / \mathrm{min}$ down to a temperature of $-30{ }^{\circ} \mathrm{C}$ or less by means of a programmable $\mathrm{LN}_{2}$-operated freezer, whereas thawing is usually performed in a water bath of 37 ${ }^{\circ} \mathrm{C}$. Numerical recoveries reported vary from 60 to $90 \%$. We believe that cooling rates at temperatures below $-40{ }^{\circ} \mathrm{C}$ are not as critical as in the upper temperature region (i.e. above $-40{ }^{\circ} \mathrm{C}$ ) and can be increased up to $10{ }^{\circ} \mathrm{C} / \mathrm{min}$ to save time. Additionally, we do not think that a programmable $\mathrm{LN}_{2}$-operated freezer is always required to generate the appropriate cooling rate: $-80{ }^{\circ} \mathrm{C}$ refrigerators may be suitable as long as provision is taken (e.g. by using card board insulations) that the cooling rate in the upper temperature region does not exceed $5{ }^{\circ} \mathrm{C} / \mathrm{min}$. It is best to document the cooling rate of $1-5^{\circ} \mathrm{C} / \mathrm{min}$ with a suitable temperature recorder. For long-term storage (i.e. months or years), however, we recommend liquid nitrogen $\mathrm{LN}_{2}\left(-196{ }^{\circ} \mathrm{C}\right)$ or the vapor $\left(\leq-165^{\circ} \mathrm{C}\right)$. In any case temperatures well below $-123{ }^{\circ} \mathrm{C}$ are needed, which is the glass transition temperature of maximally freeze concentrated aqueous DMSO solutions [41]. However, storage for a few days or weeks in $-80{ }^{\circ} \mathrm{C}$ freezers may also be acceptable but prolonged storage (months or years) requires lower temperatures.

\section{Granulocytes}

There have been publications in the past which claim the successful cryopreservation of granulocytes [reviews in e.g. 42, 43]. Despite reports appearing now and then in the newer literature (mostly as abstracts), it is our opinion that no clinically suitable method for the preservation of granulocytes has been found. The huge variation of the in vitro results shows how cumbersome the viability assays are, and how unsuitable they will be to predict anything that is going to happen in vivo. Membrane integrity tests (i.e. staining tests, often referred to as 'viability tests') measure only a conditio sine qua non (i.e. an intact cell membrane). Mature granulocytes are end stage cells designed to break down and liberate their lysosomes and lysosomal enzymes causing cell destruction. However, what is the meaning of these results if tests measuring typical granulocytic functions (e.g. chemotaxis, bactericidal activity) fail to detect any significant activity? Takahashi and co-workers [44] have proposed some explanations why granulocytes are so unrewarding regarding their cryopreservation. Already at temperatures below $-5{ }^{\circ} \mathrm{C}$ without the formation of ice, a significant loss of function can be observed. This could be prevented by the addition of DMSO, whereas glycerol failed to show this effect. Because of their limited osmotic tolerance (already a two-fold increase compared to isotonicity caused a significant loss of function), they are highly susceptible to the electrolyte enrichment taking place during ice formation. Granulocytes also showed a limited tolerance to hypotonic stress which may occur upon thawing.

\section{References}

1 Sputtek A, Körber C: Cryopreservation of red blood cells, platelets, lymphocytes, and stem cells; in Fuller BJ, Grout BWW (eds): Clinical Applications of Cryobiology. Boca Raton, CRC Press, 1991, pp 95-147.

2 Sputtek A, Sputtek R: Cryopreservation in transfusion medicine and haematology; in Fuller BJ, Lane N, Benson EE (eds): Life in the Frozen State. Boca Raton, CRC Press, 2004, pp 483-504.

3 Sputtek A: Kryokonservierung von Blutzellen und hämatopoetischen Zellen; in Mueller-Eckhardt C, Kiefel V (Hrsg): Transfusionsmedizin. Berlin, Springer, 2004, pp 133-144.
4 Rowe AW: Cryopreservation of red blood cells by freezing and vitrification - Some recollections and predictions. Infus Ther Transfus Med 2002;29: 25-30.

$\checkmark 5$ Huggins CE: Preservation of blood by freezing with dimethyl sulfoxide and its removal by dilution and erythrocyte agglomeration. Vox Sang 1963;8: 99-100.

6 Meryman HT, Hornblower M: A method for freezing and washing red blood cells using a high glycerol concentration. Transfusion 1972;12:145-156.
7 Brecher ME (ed): Technical Manual, 14th ed. Bethesda, American Association of Blood Banks, 2003, pp 741-743.

8 Sputtek A: Cryopreservation of red cells and platelets; in Day JG, Stacey G (eds): Cryopreservation and Freeze Drying Protocols, Totowa, Humana Press 2007, pp 283-301.

9 Rowe AW, Eyster E, Kellner A: Liquid nitrogen preservation of red blood cells for transfusion: a low glycerol-rapid freeze procedure. Cryobiology 1968;5:119-128. 
10 Rowe AW: Preservation of blood by the low glycerol-rapid freeze process; in American Association of Blood Banks (ed): Red Cell Freezing. Bethesda, American Association of Blood Banks, 1973, pp $55-71$.

11 Krijnen HW, Kuivenhoven ACJ, De Wit JJFM: The preservation of blood cells in the frozen state. Experiences and current methods in the Netherlands. Cryobiology 1968;5:136-143.

12 Rinfret AP: Some aspects of preservation of blood by rapid freeze-thaw procedures. Fed Proc 1963;22: 94-101.

-13 Knorpp CT, Merchant WR, Gikas PW, Spencer HH, Thompson NW: Hydroxyethyl starch: extracellular cryophylactic agent for erythrocytes. Science 1967;57:1312-1313.

14 Sputtek A, Rau G: Kryokonservierung von $\mathrm{Hu}$ manerythrozyten mit Hydroxyethylstärke (HES) Teil 1: Verfahrensbeschreibung. Infusionstherapie 1992;19:269-275.

15 Sputtek A, Bacher C, Langer R, Kron W, Henrich HA, Rau G: Kryokonservierung von Humanerythrozyten mit Hydroxyethylstärke (HES) - Teil 2: Vitalitätsanalytik. Infusionstherapie 1992;19:276-282.

-16 Sputtek A, Singbartl G, Langer R, Schleinzer W, Henrich HA, Kühnl P: Cryopreservation of red blood cells with the non-penetrating cryoprotectant hydroxyethyl starch. CryoLetters 1995;16:283-288.

17 Horn P, Sputtek A, Standl T, Rudolf B, Kühnl P, Schulte am Esch J: Transfusion of autologous, hydroxyethyl starch cryopreserved red blood cells in patients, Anaesth Analg 1997;85:739-745.

18 Sputtek A, Horn EP, Schulte am Esch J, Kühnl P. Kryokonservierung von Erythrozyten mit Hydroxyethylstärke (HES) - vom Laborversuch zur klinischen Anwendung. Anästhesiol Intensivmed Notfallmed Schmerzther 2001;36(suppl 2):162-164.

19 Sputtek A, Mingers B. Freezing container, European Patent 0786981 (Germany, Great Britain, France, Spain, Switzerland, Italy, Netherlands), Priority 17/10/1994; German Patent P 4437091 C2; US Patent 5,935,848; Canadian Patent 2,203,035; Japanese Patent 8-512944.

20 Robson DC: Rapid freezing and thawing techniques using extra-cellular agents; in: Spielmann W, Seidl S.(eds): Modern Problems of Blood Preservation. Stuttgart, Fischer, 1970, pp 204-208.
21 Thomas MJG, Perry ES, Nash SH, Bell SH: A method for the cryopreservation of red blood cells using hydroxyethyl starch as a cryoprotectant. Transfus Sci 1996;17:385-396.

22 Bell SM, Thomas MJG: Cryopreservation of human red blood cells; in Day JG, McLellan MR (eds): Cryopreservation and Freeze-Drying Protocols. Totowa, Humana Press, 1995, pp 235-250.

23 Banks W, Greenwood CT, Muir DD: The structure of hydroxyethyl starch. Br J Pharmacol 1973;47: 172-178.

24 Treib J, Baron JF, Grauer MT, Straus RG: An international view of hydroxyethyl starches. Intensive Care Med 1999;258-268.

25 Sputtek A, Körber C, Rau G: Tieftemperaturkonservierung menschlicher roter Blutkörperchen mit dem Kryoprotektiv Hydroxyethylstärke - Bedeutung der HES-Modifikation. Z Klin Med 1991;46: 1567-1570.

26 Chen T, Bhowmick S, Sputtek A, Fowler A, Toner $\mathrm{M}$ : The glass transition temperature of mixtures of trehalose and hydroxyethyl starch. Cryobiology 2202;44:301-306.

27 Klein E, Toch R, Farber S, Freeman G, Fiorentino $\mathrm{R}$ : Hemostasis in thrombocytopenic bleeding following infusion of stored, frozen platelets. Blood 1956;11:693-698.

28 Djerassi I, Farber S, Roy A, Cavins J: Preparation and in vivo circulation of human platelets preserved with combined dimethylsulfoxide and dextrose. Transfusion 1966;6:572-576.

29 Lundberg A, Yankee RA, Henderson ES, Pert JH: Clinical effectiveness of blood platelets preserved by freezing. Transfusion 1967;7:380-381.

30 Schiffer CA, Aisner J, Dutcher JP: Platelet cryopreservation using dimethyl sulfoxide. Ann NY Acad Sci 1985;459:161-169.

31 Walker RH (ed): Technical Manual, 11th ed. Bethesda, American Association of Blood Banks, 1993, pp 733-737.

32 Dayian G, Rowe AW: Cryopreservation of human platelets for transfusion. A glycerol-glucose, moderate rate cooling procedure. Cryobiology 1976;13: $1-8$

33 Choudhury C, Gunstone MJ: Freeze preservation of platelets using hydroxyethyl starch (HES): a preliminary report. Cryobiology 1978;15:493-501.
34 Sputtek A, Brohm A, Classen I, Hartmann U, Körber C, Scheiwe MW, Rau G: Cryopreservation of human platelets with hydroxyethyl starch in a onestep procedure. CryoLetters 1987;8:216-229.

35 Sputtek A, Barthel B, Rau G: Cryopreservation of human platelets: an in vitro comparison of a 4\% HES method with the standard 5\% DMSO method. Cryobiology 1993;30:656-657.

36 Cohen E, Rowe AW: Detection of leukoagglutinins with dimethyl sulfoxide (DMSO) protected leukocytes frozen with liquid nitrogen. Vox Sang 1965; 10:543-551.

37 Ashwood-Smith MJ: Preservation of mouse marrow at $-79{ }^{\circ} \mathrm{C}$ with dimethyl sulphoxide. Nature 1961;190:1204-1205.

38 Stiff PJ: Cryopreservation of hematopoietic stem cells; in Lasky LC, Warkentin PI (eds): Marrow and Stem Cell Processing for Transplantation. Bethesda, American Association of Blood Banks, 1995, pp 69-82.

39 Pegg DE, Wusteman MC, Boylan S: Fractures in elastic arteries. Cryobiology 1997;34:183-192.

40 Sputtek A, Jetter S, Hummel K, Kühnl P: Cryopreservation of peripheral blood progenitor cells: characteristics of suitable techniques; in Sibrowski W, Stangel W, Blauhut B (Hrsg): Transfusionmedizin 1995/96. Beitr Infusionsther Transfusionsmed. Basel, Karger, 1997, vol 34, pp 79-83.

41 Sputtek A, Gutensohn K, Hummel K, Löliger, C, Kühnl P: Zur Kryokonsrvierung von Blutstammzellen. J Lab Med 1996;20:70-77.

42 Bank H: Granulocyte preservation circa 1980. Cryobiology 1980;17:187-197.

43 Knight SC: Preservation of leucocytes; in Ashwood-Smith MJ, Farrant J (eds): Low Temperature Preservation in Medicine and Biology. Tunbridge Wells, Pitman Medical, 1980, pp 121-138.

44 Takahashi T, Hammett M, Cho MS: Multifaceted freezing injury in human polymorphonuclear cells at high subfreezing temperatures. Cryobiology 1985;22:215-236. 